\title{
Role of oncology clinical pharmacist: a case of life-saving interventions
}

\author{
Osama M. Al-Quteimat*, Mariam A. Al-Badaineh
}

Pharmaceutical Care Department, King Abdullah Medical City, Kingdom of Saudi Arabia, Makkah

Received: 15 August 2013

Accepted: 24 August 2013

*Correspondence to:

Osama M. Al-Quteimat,

Email: systemman86@yahoo.com

(C) 2013 Al-Quteimat OM et al. This is an open-access article distributed under the terms of the Creative Commons Attribution NonCommercial License, which permits unrestricted noncommercial use, distribution, and reproduction in any medium, provided the original work is properly cited.

\begin{abstract}
The oncology clinical pharmacist (CP) has a crucial role in cancer patient care through improving medication use including chemotherapy and other high alert medications. As part of multidisciplinary team $\mathrm{CP}$ has major role in assuring safe, effective and cost-effective drug therapy. Herein we report a case of 45 years old male patient diagnosed with diffuse large B-cell lymphoma (DLBCL), treated with high dose methotrexate (MTX) as prophylaxis for central nervous system (CNS) lymphoma, and followed up by $\mathrm{CP}$ regarding medications related issues. Role of $\mathrm{CP}$ is mainly to identify, prevent and manage any drug related problem including drug choice, dosage, interactions, administration and side effects. Oncology CP was very effective in optimizing medication use and has a promising role through providing clinically important interventions regarding medication use. We present this educational case report to show the vital role of $\mathrm{CP}$ in patient care by providing important interventions that are effective and sometimes lifesaving.
\end{abstract}

Keywords: Clinical pharmacy, Methotrexate, Oncology, Chemotherapy, Pharmaceutical care

\section{INTRODUCTION}

$\mathrm{CP}$ role is emerging as vital addition to the health care team resulting in improved patient care. Interacting with health care professionals on rounds, patient interview, medication reconciliation, and providing patient discharge counseling and follow-up all resulted in improved outcomes. ${ }^{1}$ In oncology setting, CP has a major role in the adjustment of medications and being part of multidisciplinary team is recommended to prevent and manage medications errors. ${ }^{2}$

$\mathrm{CP}$ has to follow and evaluate the chemotherapy protocols regarding appropriate doses, potential drug interactions and side effects management to achieve safe and effective drug therapy and to prevent medication errors. CP has potential role in symptoms management and was effective in optimizing the use of antiemetic for chemotherapy induced nausea and vomiting. ${ }^{3}$ Pain management is another field were clinical pharmacist interventions were effective in improving safety, efficacy and patient satisfaction. ${ }^{4}$ Also CP participation in patient care is important to improve patient compliance to the prescribed medications and avoidance of cost-ineffective drug therapy. ${ }^{5}$

\section{CASE REPORT}

\section{Case summary}

We report a case of 42 years old male patient with NonHodgkin Lymphoma (DLBCL), treated by R-CHOP chemotherapy protocol (Rituximab, Cyclophosphamide, Doxorubicin, Vincristine and Prednisone); he received 4 cycles of R-CHOP and admitted for CNS lymphoma prophylactic by high dose MTX chemotherapy. Patient was diagnosed with stage III lymphoma with 2 extranodal sites of disease and involvement of paranasal sinuses. The patient weight is $82 \mathrm{~kg}$ and height is $175 \mathrm{~cm}$, he is medically free, except for osteoarthritis which is wellcontrolled by Ibuprofen.

\section{Signs and symptoms}

The patient was doing well with stable vital signs and performance status of 1 on ECOG score, but had enlarged 
axillary lymph nodes, mild heart burn, constipation and moderate ascites.

\section{Relevant lab tests}

Albumin $1.48 \mathrm{~g} / \mathrm{dl}$, Liver Enzymes (ALT $45 \mathrm{IU} / \mathrm{L}$, AST $32 \mathrm{IU} / \mathrm{L})$, Total Bilirubin: $0.53 \mathrm{mg} / \mathrm{dl}$, Phosphate 7.7 $\mathrm{mg} / \mathrm{dl}$, Potassium $3.6 \mathrm{mEq} / \mathrm{L}$, Uric Acid $8.8 \mathrm{mg} / \mathrm{dl}$, Magnesium $2.3 \mathrm{mEq} / \mathrm{L}$, Sodium $138 \mathrm{mEq} / \mathrm{L}$, Chloride 98 $\mathrm{mEq} / \mathrm{L}$, Neutrophils count 1100/ $\mu \mathrm{L}$, Platelets $170,000 / \mu \mathrm{L}$, White Blood Cells $1600 \mu \mathrm{L}$, Serum Creatinine $0.89 \mathrm{mg} / \mathrm{dl}$, Calcium $7.5 \mathrm{mg} / \mathrm{dl}$, Lactate Dehydrogenase 620 IU/L.

- Calculated Creatinine Clearance using Cockcroft and Gaul formula: $104 \mathrm{ml} / \mathrm{min}$.

- Calculated body surface area (BSA) using Mosteller Method: $2 \mathrm{~m}^{2}$.

\section{Current medications}

\begin{tabular}{|l|ll|l|}
\hline Medication & $\begin{array}{l}\text { Dose } \text { \& } \\
\text { Frequency }\end{array}$ & Route & Indication \\
\hline Omeprazole & $\begin{array}{l}\text { 20 mg once } \\
\text { daily }\end{array}$ & Oral & $\begin{array}{l}\text { Stress ulcer } \\
\text { prophylaxis }\end{array}$ \\
\hline TMP-SMX* & $\begin{array}{l}\text { 960 mg } \\
\text { every } 48 \\
\text { hours }\end{array}$ & Oral & $\begin{array}{l}\text { PCP } \\
\text { prophylaxis }\end{array}$ \\
\hline $\begin{array}{l}\text { Calcium } \\
\text { Carbonate }\end{array}$ & $\begin{array}{l}500 \mathrm{mg} \mathrm{3} \\
\text { times daily }\end{array}$ & Oral & Hypocalcemia \\
\hline Senna & $\begin{array}{l}24 \mathrm{mg} \text { once } \\
\text { daily }\end{array}$ & Oral & Constipation \\
\hline Ibuprofen & $\begin{array}{l}400 \mathrm{mg} 3 \\
\text { times daily }\end{array}$ & Oral & Osteoarthritis \\
\hline
\end{tabular}

*Trimethoprim-Sulfamethoxazole, ${ }^{* *}$ PCP: Pneumocystis Carinii Pneumonia

\section{Plan}

Therapeutic plan was to give intravenous (I.V) high dose MTX for CNS lymphoma prophylaxis according to the following protocol (body surface area $=2 \mathrm{~m}^{2}$ ):

\section{Urine Alkalanization:}

Start oral sodium bicarbonate $1.5 \mathrm{~g}$ every 6 hours. Dipstick urine every 2 hours to check $\mathrm{PH}$. If $\mathrm{pH}<7$ give additional bicarbonate.

\section{Hydration:}

Start IV hydration 12 hours before administration of MTX with Sodium chloride $0.45 \%$ with sodium bicarbonate $50 \mathrm{mEq}$ per liter at rate of $150 \mathrm{ml} / \mathrm{hour}$.

Continue hydration throughout and post MTX administration until MTX level is less than $0.05 \mathrm{mcg} / \mathrm{ml}$.

\section{Premedications:}

Ondansetron $8 \mathrm{mg}$ I.V. once pre MTX.

Dexamethasone $8 \mathrm{mg}$ I.V. once pre MTX.

\section{Chemotherapy:}

Methotrexate $\left(3.5 \mathrm{gm} / \mathrm{m}^{2}\right)=7$ grams in Dextrose $5 \%$ in water $1000 \mathrm{~mL}$ IV over 6 hours on day 1 .

Leucovorin $\left(25 \mathrm{mg} / \mathrm{m}^{2}\right)=50 \mathrm{mg}$ IV beginning 24 hours after the start of MTX and continue every 6 hours until the serum MTX level is $<0.05 \mathrm{mcg} / \mathrm{ml}$.

* Check urine pH every 8 hours. If less than 7, give sodium bicarbonate $50 \mathrm{mEq}$ IV.

* Therapeutic drug monitoring (MTX post-dose level):

MTX levels every morning at 24, 48 and 72 hours after the completion of MTX and continue daily until serum MTX level is $<0.05 \mathrm{mcg} / \mathrm{ml}$. ${ }^{6,7}$

\section{Clinical pharmacist interventions}

1- To stop TMP-SMX one week before chemotherapy, since it associated with serious and fatal interaction that increases risk of MTX toxicity.

2- Drainage of the ascites should be done before initiation of MTX; consider adding Albumin (20\%) $100 \mathrm{ml}$ every 12 hours and Furosemide $20 \mathrm{mg}$ every 12 hours to resolve ascites before MTX therapy to prevent MTX toxicity.

3- To replace Omeprazole $20 \mathrm{mg}$ with oral Ranitidine $150 \mathrm{mg}$ twice daily to avoid the interaction between proton pump inhibitors (PPIs) and MTX.

4- To hold Ibuprofen and resume (if needed) after MTX level decreased to $<0.05 \mathrm{mcg} / \mathrm{ml}$ since non-steroidal antiinflammatory drugs (NSAIDs) interfere with the excretion of MTX and may potentiate toxicity; consider oral Paracetamol $1000 \mathrm{mg} 4$ times daily as alternative.

5- To add oral Allopurinol $300 \mathrm{mg}$ once daily and oral Sevelamer $800 \mathrm{mg}$ three times daily to treat hyperuricemia and hyperphosphatemia, respectively.

6- Consider stopping Calcium Carbonate replacement if there is no other indication.

\section{Follow up}

- Pre-hydration was given as recommended by the protocol $(150 \mathrm{ml} / \mathrm{hr})$. CP found that post-hydration was given as $15 \mathrm{ml} / \mathrm{hr}$ for 6 hours (instead of $150 \mathrm{ml} / \mathrm{hr}$ ) due to nurse mistake, assigned consultant was informed and 
the decision was to hold the post-hydration and to give 1 liter of sodium chloride $0.45 \%$ over 2 hours, then posthydration was resumed as $150 \mathrm{ml} / \mathrm{hr}$ again as it should be.

\section{- After 24 hours:}

MTX level was $57 \mathrm{mcg} / \mathrm{ml}$, urine $\mathrm{PH}$ was 7 , serum creatinine increased from $0.89 \mathrm{mg} / \mathrm{dl}$ to $2.1 \mathrm{mg} / \mathrm{dl}$, Total Bilirubin $0.5 \mathrm{mg} / \mathrm{dl}$ and Liver enzymes elevated (ALT $152 \mathrm{IU} / \mathrm{L} \&$ AST $121 \mathrm{IU} / \mathrm{L})$. Patient developed mild dermatitis on the back, nausea and vomiting. Also the patient complained of diarrhea for which Loperamide was prescribed. No pulmonary or neurological changes were observed.

The CP recommended the following actions:

7- Continue intravenous hydration with addition of Furosemide $20 \mathrm{mg}$ twice daily to maintain urine adequate output.

8- Increase Leucovorin dose to be $100 \mathrm{mg}$ every 6 hours and continue until MTX level $<0.05 \mathrm{mcg} / \mathrm{ml}$.

9- Continue oral Sodium Bicarbonate as $1.5 \mathrm{~g}$ every 6 hours to maintain urine $\mathrm{PH}>7$, preferably $>8$.

\section{- After 48 hours:}

MTX level has dropped to $1.88 \mathrm{mcg} / \mathrm{ml}$, urine PH was 8 , serum creatinine decreased to $1.42 \mathrm{mg} / \mathrm{dl}$ with continuous hydration, Total Bilirubin $0.52 \mathrm{mg} / \mathrm{dl}$, Liver Enzymes decreased (ALT 73 IU/L, AST 68 IU/L) and patient is still suffering from the symptoms of diarrhea and dermatitis.

\section{- After 72 hours:}

MTX level was decreased to $0.08 \mathrm{mcg} / \mathrm{ml}$ and the patient was stable, symptoms of diarrhea and dermatitis improved and patient was discharged 5 days later.

\section{DISCUSSION}

DLBCL, the most common histological type of nonHodgkin's lymphoma, is an aggressive disease associated with CNS secondary involvement in 3-5\% of cases and mainly treated with the R-CHOP chemotherapy protocol. Rate of CNS involvement is dramatically increased in patients with certain risk factors at the time of diagnosis. ${ }^{6}$

Elevated LDH, age >60 years, involvement of >1 extranodal site, hypoalbuminemia and high International Prognostic Index (IPI) score are common risk factors for secondary CNS lymphoma. Patients with $\geq 2$ of these risk factors should receive prophylaxis either with intrathecal or high-dose systemic chemotherapy. ${ }^{8}$ Our patient had $>2$ risk factors, so the decision was to give high dose MTX as CNS prophylaxis. The patient was taking TMP-SMX for PCP prophylaxis. CP recommendation was to stop this medication 1 week before starting MTX therapy because there is a well-documented fatal drug interaction between MTX and TMP-SMX causing increased risk of MTX toxicity like serious pancytopenia ${ }^{9}$, so this intervention by CP is very important and considered lifesaving.

The use of high dose MTX is contraindicated in the presence of a third space fluid like pleural effusions or ascites. Presence of ascites will prolong MTX plasma half life and increase the risk of toxicity. It is recommended to drain the accumulated fluid before MTX therapy. ${ }^{10}$

Using PPIs concurrently with MTX is considered major risk factor for delayed MTX elimination and increased toxicity, so PPIs should not be used during MTX therapy. ${ }^{11}$ Thus, the $\mathrm{CP}$ recommendation was to discontinue Omeprazole and use Ranitidine $150 \mathrm{mg}$ twice daily as safe alternative. Similarly, MTX elimination is also impaired in patients receiving concurrent NSAID therapy like Ibuprofen. So it is recommended to avoid such combination. ${ }^{12}$

Patients treated with chemotherapy for DLBCL are at high risk for tumor lysis syndrome (TLS). Allopurinol for hyperuricemia and Sevelamer for hyperphosphatemia were recommended to this patient as treatment and also as prophylaxis for TLS. ${ }^{13}$ There is no clear indication for Calcium Carbonate replacement in this patient. Calcium level is $7.5 \mathrm{mg} / \mathrm{dl}$ and albumin level is also low, but corrected calcium level is $9.52 \mathrm{mg} / \mathrm{dl}$ which is normal.

When MTX toxicity is suspected based on high MTX level and symptoms, maintaining urine output, urinary alkalinization, monitoring serum creatinine, electrolytes and plasma MTX concentrations, and pharmacokinetically-guided leucovorin rescue, are the cornerstones of management for patients who develop early signs of renal dysfunction and delayed MTX elimination. ${ }^{14} \mathrm{CP}$ recommendations were mainly directed to adjust Leucovorin dose, maintain urine $\mathrm{PH}>7$ and continuous hydration.

This case report clearly shows the important role of the oncology CP as a member of the oncology multidisciplinary team, in optimizing medication use to achieve safe, effective and cost-effective drug therapy. By providing therapeutic interventions, $\mathrm{CP}$ can monitor, detect, prevent, and manage many serious and sometimes fatal drug-related problems.

Funding: No funding sources Conflict of interest: None declared

Ethical approval: Not required 


\section{REFERENCES}

1. Peter J. Kaboli, Angela B, et al. Clinical Pharmacists and Inpatient Medical Care: A Systematic Review. Arch Intern Med 2006;166:955-64.

2. Jolynn K. Sessions, John Valgus, et al. Oncology Clinical Pharmacists in Light of the Oncology Workforce Study. J Oncol Pract 2010 September; 6(5):270-2.

3. Chan A, Shih V, Chew L. Evolving roles of oncology pharmacists in Singapore: a survey on prescribing patterns of antiemetics for chemotherapy induced nausea and vomiting (CINV) at a cancer centre. J Oncol Pharm Pract 2008 Mar;14(1):23-9.

4. Ryan N, Chambers C, Ralph C, England D, Cusano F. Evaluation of clinical pharmacists' follow-up service in an oncology pain clinic. J Oncol Pharm Pract 2013;19:151-8.

5. Altavela JL, Jones MK, Ritter M. A prospective trial of a clinical pharmacy intervention in a primary care practice in a capitated payment system. J Manag Care Pharm 2008 Nov-Dec;14(9):831-43.

6. Jeremy S. Abramson, Matthew Hellmann, Jeffrey A. Barnes, et al. Intravenous Methotrexate as Central Nervous System (CNS) Prophylaxis Is Associated With a Low Risk of CNS Recurrence in High-Risk Patients With Diffuse Large B-Cell Lymphoma. Cancer 2010;116:4283-90.

7. Bernstein JI, Coleman CN, et al. Combined modality therapy for adults with small non cleaved cell lymphoma (Burkitt's and non-Burkitt's types). J Clin Oncol 1986 Jun;4(6):847-58.
8. Cheung $\mathrm{CW}$, Burton $\mathrm{C}$, Smith $\mathrm{P}$, et al. Central nervous system chemoprophylaxis in non-Hodgkin lymphoma: current practice in the UK. Br J Haematol 2005 Oct;131(2):193-200.

9. Al-Quteimat OM, Al-Badaineh MA. Methotrexate and trimethoprim-sulphamethoxazole: extremely serious and life-threatening combination. Journal of Clinical Pharmacy and Therapeutics. 2013, doi: 10.1111/jcpt.12060.

10. Emna Gaies, Nadia Jebabli, Sameh Trabelsi, et al. Methotrexate Side Effects: Review Article. J Drug Metab Toxicol 2012;3:125.

11. R. Santucci, D. Leveque, A. Lesocoute, et al. Delayed Elimination of Methotrexate Associated with Co-Administration of Proton Pump Inhibitors. Anticancer Research 2010;30:3807-10.

12. Johnson AG, Seidemann P, Day RO. NSAID-related adverse drug interactions with clinical relevance. An update. Int J Clin Pharmacol Ther 1994 Oct;32(10):509-32.

13. Ali McBride, Peter Westervelt. Recognizing and managing the expanded risk of tumor lysis syndrome in hematologic and solid malignancies. Journal of Hematology \& Oncology 2012;5:75.

14. Brigitte C. Widemann, Peter C. Adamson. Understanding and Managing Methotrexate Nephrotoxicity. The Oncologist 2006;11:694-703.

doi:10.5455/2319-2003.ijbcp20131028

Cite this article as: Al-Quteimat OM, Al-Badaineh MA. Role of oncology clinical pharmacist: a case of life-saving interventions. Int J Basic Clin Pharmacol 2013;2:655-8. 